\title{
Fungicidal activity and constituents of Ageratum conyzoides essential oil from three regions in São Paulo state, Brazil
}

\section{Atividade fungicida e constituintes químicos do óleo essencial de Ageratum conyzoides de três regiões do estado de São Paulo, Brasil}

\author{
Renata Haddad Esper ${ }^{1}$, Edlayne Gonçalez ${ }^{1}$, Roberto Carlos Felicio², Joana Darc Felicio ${ }^{1 *}$

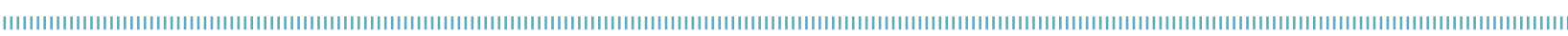

\begin{abstract}
The chemical composition and antifungal activity of the Ageratum conyzoides essential oils, obtained from the leaves collected in Ibiúna (1), Ribeirão Pires (2) and Campinas (3) in the São Paulo state, Brazil, were investigated. The essential oils were obtained from $A$. conyzoides leaves by hydrodestilation and analyzed by GC/MS. The chemical composition of the $A$. conyzoides oil collected in Ribeirão Pires and Ibiúna consisted mainly of precocene I and II. The essential oil from leaves collected in Campinas had only traces of precocene II and a highest proportion of precocene I, $\alpha$-humulene and (E)-caryophyllene than the oils (1) and (2). The Aspergillus flavus growth was inhibited by essential oils (1) and (2) at 60 and 64\%, respectively, and the oil (3) was inactive. On the other hand, the three essential oils inhibited the sporulation of the fungus for more than 120 days. The essential oils of leaves collected in sites that show similarities in the latitude, altitude and average temperatures, as Ribeirão Pires and Ibiúna, showed chemical composition and antifungal activity similar, either, which showed the importance of geo-ecological factors in production of metabolites of the plant.
\end{abstract}

KEYWORDS: Ageratum conyzoides; essential oil; Aspergillus flavus; antifungal activity; Asteraceae.
RESUMO: A composição química e a atividade antifúngica do óleo essencial de folhas de Ageratum conyzoides, coletadas em Ibiúna (1), Ribeirão Pires (2) e Campinas (3) no estado de São Paulo, foram investigadas. Os óleos essenciais foram obtidos a partir de folhas de A. conyzoides por hidrodestilação e analisados por CG/EM. A composição química do óleo essencial de $A$. conyzoides coletadas em Ribeirão Pires e Ibiúna consiste principalmente de precoceno I e II. O óleo essencial das folhas coletadas em Campinas possui apenas traços de precoceno II e uma maior proporção de precoceno I, $\alpha$-humuleno e (E)-cariofileno quando comparado com os óleos (1) e (2). O crescimento de Aspergillus flavus foi inibido pelos óleos essenciais (1) e (2) em 60 e 64\%, respectivamente, enquanto que o óleo (3) foi inativo. Por outro lado, os três óleos essenciais inibiram a esporulação do fungo por mais de 120 dias. Os óleos essenciais de folhas coletadas em locais que mostram semelhanças na latitude, altitude e temperatura média, como Ribeirão Pires e Ibiúna, mostraram composição química e atividade antifúngica semelhante. Isso mostrou a importância dos fatores geo-ecológicos na produção de metabólitos da planta.

PALAVRAS-CHAVE: Ageratum conyzoides; óleo essencial; Aspergillus flavus; atividade fungicida; Asteraceae. 
The genus Ageratum consists of approximately 30 species but only a few species have been phytochemically investigated (Okunade, 2002; Vieira et al.; 2009). Ageratum conyzoides L. (mentrasto) have been used in folk medicine for the treatment of pneumonia, infections, asthma, fevers, inflammation, diarrhea etc. (Almagboul et al., 1985; Marques-Neto et al., 1988; Magalhâes et al., 1998; Moura et al., 2005).

The antimicrobial and insecticidal activities are one of the most important biological activities of the A. conyzoides (Martins et al., 2005).

A. conyzoides essential oil is reported to contain mainly terpinene-4-ol, bornyl acetate, E-caryophyllene, $\gamma$-muroleno, $\delta$-cadinene, $\alpha$-muroleno, caryophyllene oxide, $\alpha$-humulene, precocene I and II. The precocenes are major compounds of oil with variations from 30 to $93 \%$ (CASTRO et al., 2004).

A. conyzoides essential oil possesses antifungal activities against Aspergillus flavus and inhibitory effect on aflatoxin production (Nogueira et al., 2010). A. flavus can produce aflatoxins $\mathrm{B}_{1}$ and $\mathrm{B}_{2}\left(\mathrm{AFB}_{1}, \mathrm{AFB}_{2}\right)$ and cyclopiazonic acid $(\mathrm{CPA})$, and the co-production of these mycotoxins can result in an additive or synergistic toxic effect on consumers (GQALENI et al., 1997). Aflatoxins are considered carcinogens (Class 1 group), especially $\mathrm{AFB}_{1}$ (IARC, 1993). The literature showed that the yield of essential oils, their chemical constituent and their biological activity are influenced by genetic and environmental factors (XIE et al., 2012).

The aim of the present study was to evaluate the main chemical composition and activity in A. flavus growth of the essential oils from the leaves of $A$. conyzoides collected at three different localities in São Paulo state.

Leaves of $A$. conyzoides were collected at three different localities in São Paulo state (Ibiúna, Campinas and Ribeirão Pires) in June 2008. The plant was deposited in the herbarium of the City of São Paulo (PMSP 9686). Fresh leaves (300 g) were submitted to the hydro-distillation, so the essential oil was obtained. It was used by test in A. flavus and GC/MS analyses.

GC/MS analyses of the main components of the essential oils were done in a Shimadzu QP-5000 equipped with an OV-5 (30 m $\times 0.25 \mathrm{~mm} \times 0.25 \mu \mathrm{m}$, Ohio Valley Specialty Chemical, Inc.) capillary column. Operating conditions were undertaken at oven temperature from 60 to $240^{\circ} \mathrm{C}$ at $3^{\circ} \mathrm{C} / \mathrm{min}$, injector and detector temperatures of 240 and $230^{\circ} \mathrm{C}$, respectively, at $70 \mathrm{eV}$. The oil components were identified using retention indices with those of authentic compounds or with literature data (McLafferty; StaufFer, 1989).

The strain of $A$. flavus producing $\mathrm{AFB}_{1}$ was donated by the Reference Laboratory of Microbiology located at the Instituto de Tecnologia de Alimentos (ITAL), Campinas, São Paulo, Brazil. The strains are inoculated into tubes containing potato dextrose agar (Difco Laboratories, for 10 days at $25^{\circ} \mathrm{C}$ ). The spore suspension used as inoculum was prepared by washing cultures with sterile $0.01 \%$ solution of Tween 80 .
For antifungal assay, filter paper disks ( $6 \mathrm{~mm}$ diameter) containing $5.0 \mu \mathrm{L}$ of each essential oil of $A$. conyzoides were applied on the potato dextrose agar medium in Petri dishes previously inoculated with $A$. flavus inoculum on the surface. The inoculated plates were incubated at $25^{\circ} \mathrm{C}$ for 5 days. At the end of the period, antifungal activity was evaluated by measuring the zone of inhibition $(\mathrm{mm})$ against the test fungus (YIN; TSAO, 1999); $5.0 \mu \mathrm{L}$ of the commercial fungicide $(1 \mathrm{mg} / \mathrm{mL})$ were used as a positive control. All treatments consisted of three replicates, and the averages of the experimental results were determined. The fungal growth was assessed using analysis of variance (ANOVA) with significance level of $p<0.05$ and Tukey-Kramer analysis of variance for multiple comparisons with significance level $\mathrm{p}<0.05$.

The essential oil yield [w/w, fresh weight (f.w.)] of three $A$. conyzoides varied from 0.11 to $0.19 \%$. The highest yield was obtained in the plant collected in Ibiúna. The latitude, altitude, longitude and average temperatures are presented in Table 1.

The identification of compounds represented 98.58; 96.46; and $95.57 \%$ for essential oil collected in Ribeirāo Pires, Campinas and Ibiúna, respectively. The three oil essential have shown some differences in chemical constitutions (Table 2). Essential oil from leaves collected in Campinas is composed at $81.25 \%$ of precocene I and only traces of precocene II. On the other hand, the precoceno II from Ribeirão Pires and Ibiuna samples appeared in greater proportions $10.39 \%$ and $54.99 \%$, respectively. Precocene I is the main constituent in the sample from Campinas and Ribeirão Pires; on the order hand, precocene II is the main constituent of essential oil of leaves collected in Ibiúna (Table 2). (E)-caryophyllene and $\alpha$-humulene were also identified in the three oils, but in higher concentrations in the essential oil from Campinas. Higher concentrations of (E)-caryophyllene in the essential oil of $A$. conyzoides were also related by literature (RANA; BLAzQuez, 2003).

The results confirmed that the geographical variation may influence the composition of oil in a quantitative or qualitative extent. The environmental conditions, to which the plant was submitted, have major implications in their chemical composition. The differences in chemical composition of

Table 1. Latitude, longitude, altitude, average maximum temperature and average minimum temperature of local of collection*.

\begin{tabular}{lrrr} 
& Ibiúna & Ribeirão Pires & Campinas \\
\hline Latitude & $-23^{\circ} 23^{\prime}$ & $-23^{\circ} 25^{\prime}$ & $-22^{\circ} 31^{\prime}$ \\
\hline Longitude & $47^{\circ} 7^{\prime}$ & $46^{\circ} 15^{\prime}$ & $47^{\circ} \mathrm{O} 2^{\prime}$ \\
\hline Altitude $(\mathrm{m})$ & 880 & 800 & 680 \\
\hline AMaxT $\left({ }^{\circ} \mathrm{C}\right)$ & 22.8 & 22.8 & 29.0 \\
\hline AMinT $\left({ }^{\circ} \mathrm{C}\right)$ & 8.5 & 9.0 & 11.0 \\
\hline
\end{tabular}

*Taken from the site www.cpa.unicamp.br/outras-informacoes/climados-municipios-paulistas.html.

AMaxT: average maximum temperature; AMinT: average minimum temperature. 
Table 2. Chemical composition of essential oils of leaves of $A$. conyzoides collected in Campinas, Ribeirão Pires and lbiúna.

\begin{tabular}{lcccccc} 
Chemical compounds & $\begin{array}{c}\text { EOC } \\
\text { (\%) }\end{array}$ & $\begin{array}{c}\text { EORP } \\
(\%)\end{array}$ & $\begin{array}{c}\text { EOI } \\
(\%)\end{array}$ & IR* $^{*}$ & IR $^{*}$ \\
n-tetradecane & 0.60 & $\operatorname{tr}$ & $\operatorname{tr}$ & 1400 & 1400 \\
\hline (E)-caryophyllene & 13.36 & 8.39 & 11.45 & 1416 & 1418 \\
\hline$\alpha$-humulene & 1.25 & 0.69 & $\operatorname{tr}$ & 1449 & 1454 \\
\hline Dimethoxi ageratocromene (precocene I) & 81.25 & 79.11 & 29.13 & 1454 & 1463 \\
\hline Ageratocromene (precocene II) & $\operatorname{tr}$ & 10.39 & 54.99 & 1659 & 1660 \\
\hline
\end{tabular}

*Experimental retention index; ** retention index literature (ADAMS, 2007).

EOC: Campinas; EORP: Ribeirão Pires; EOI: Ibiúna; tr: trace of the substance ( $\operatorname{tr} \leq 0.59)$.

three essential oils probably cannot be attributed to latitude and longitude of the three cities, because there are no major differences. The biggest difference among the three locations is the average of the maximum and minimum temperatures. The temperatures of Ribeirão Pires and Ibiúna are lower and similar; the average temperatures in Campinas are higher (Table 1). The proportion of precocene II increases with the increase of altitude, while constituents like precocene I and $\alpha$-humulene increase in quantity with a decrease in altitude. HAIDER et al. (2010) related the increase of $\alpha$-humulene in the Artemisia nilagirica var. septentrionalis essential oil with the decrease in altitude, a fact that was also observed by us. A. conyzoides essential oil from Ibiúna $(880 \mathrm{~m})$ contains only trace of $\alpha$-humulene, while $A$. conyzoides essential oil from Campinas $(680 \mathrm{~m})$ contains $1.25 \%$ of $\alpha$-humulene.

The fungal growth inhibition assessed by the disk diffusion test has been used in the evaluation of plant extracts and essential oils by several authors. The influence of the essential oils on the inhibitory zone against $A$. flavus was measured at $2.5,1.6$ and $1.5 \mathrm{~cm}$ for commercial fungicide, essential oils of leaves collected in Ribeirão Pires and in Ibiúna respectively; on the other hand, the essential oil from Campinas did not form halo of inhibition. The percentages of the fungal growth inhibition were 64 and $60 \%$ for essential oils of leaves collected in Ribeirão Pires and Ibiúna, respectively (Table 3). The $A$. conyzoides essential oils from Ribeirão Pires and Ibiúna inhibited A. flavus growth, were similar and did not have statistically significant difference $(\mathrm{p}>0.05)$.

A. flavus sporulation was inhibited by three essential oils and this inhibition persisted for more 120 days, showing fungistatic activity for the three essential oils.

Ribeirão Pires and Ibiúna essential oils showed similar chemical composition and antifungal activity, an expected result since biological activities are correlated to the presence of secondary metabolites. The season, the soil, even the number of hours that plants receive sunlight or rain may influence the phytochemistry of the plant since some compounds may be accumulated in response to environmental changes (КАMATOU et al., 2010). The significant variation in the composition of the essential oils of $A$. conyzoides leaves collected in Ibiúna and Ribeirão Pires and of the essential oil of A.conyzoides leaves collected in Campinas can be attributed to different
Table 3. Essential oils of leaves of $A$. conyzoides collected in Campinas, Ribeirão Pires and Ibiúna, size of inhibition zone, and $A$. flavus growth inhibition.

\begin{tabular}{lcc}
$\begin{array}{l}\text { Essential oils } \\
(5.0 \mu \mathrm{L})\end{array}$ & $\begin{array}{c}\text { Size of inhibition } \\
\text { zone }(\mathrm{cm})\end{array}$ & $\begin{array}{c}\text { A. flavus growth } \\
\text { inhibition }(\%)\end{array}$ \\
\hline Control & $2.15 \pm 0.115$ & 100 \\
\hline EOC & 0 & 0 \\
\hline EORP & $1.6 \pm 0.073$ & 64 \\
\hline EOI & $1.5 \pm 0.083$ & 60 \\
\hline
\end{tabular}

EOC: Campinas; EORP: Ribeirão Pires; EOI: Ibiúna.

geographical locations, environmental conditions and abiotic factors to which the plants were exposed.

The A. flavus growth inhibition by essential oil could be due to precocene II, confirming the hypothesis of Nogueira et al. (2010), who attributed the antifungal activity of $A$. conyzoides to the presence of this compound. However, sporulation inhibition can be related with synergism of essential oil's substances.

FurLan et al. (2010) reported chemical variability of the Cymbopogon citratus essential oils collected in different regions of São Paulo state. They attributed this variation to the occurrence of climatic factors and the phytogeography. Moreover, the environmental and the genetic factors are very important. Other authors also reported the chemical variation of the essential oils of plants from different ecological regions in several countries as China, Iran and Argentina (RAhimmalek et al., 2009; XIE et al., 2012).

These results suggested that the difference in chemical composition of essential oils can be attributed to climatic variations proper of different locations, which showed the importance of geo-ecological factors in the production of metabolites of the plant.

\section{ACKNOWLEDGEMENT}

The authors are grateful to the Fundação de Amparo à Pesquisa do Estado de São Paulo (FAPESP), for supporting the research, and Conselho Nacional de Desenvolvimento Científico e Tecnológico (CNPq), for the scholarship of R. H. Esper. 


\section{REFERENCES}

ADAMS, R.P. Identification of essential oil components by gas cromatography/mass spectroscopy. Allured Publ. Corp., 2007.

ALMAGBOUL, A.Z; FARROQ, A.A.; TYAGI, B.R. Antimicrobial activity of certain sudanese plants used in folkloric medicine: Screening for antibacterial activity, part II. Fitoterapia, v.56, p.103-109, 1985.

ANGIRAS, N.N. Proceedings of Seminar on Control of Lantana and Ageratum Species. Palampur: Himachal Pradesh Agricultural University, 1988.

CASTRO, H.G.; OLIVEIRA, L.O.E.; ALMEIDA, L.C.B.; FERREIRA, F.A.; SILVA, D.J.H; MOSQUIM, P.R.; NASCIMENTO, E.A. Teor e composição do óleo essencial de cinco acessos de mentrasto. Química Nova, v.27, p.55-57, 2004.

FURLAN, M.R.; MARTINS, R.C.C.; RODRIGUES, E.; SCALCO, N.; NEGRI, G.; LAGO, J.H.G. Variation in the amounts of volatile constituents of Cymbopogon citratus (DC) Staf, Poaceae, collected in different regions of São Paulo State. Brazilian Journal of Pharmacognosy, v.20, p. 686-691, 2010.

GQALENI, N.; SMITH, J.E.; LACEY, J.; GETTINBY, G. Effects of temperature, water activity, and incubation time on production of aflatoxins and cyclopiazonic acid by isolate of Aspergillus flavus in surface agar culture. Applied Environmental Microbiology, v.63, p.1048-1053, 1997.

HAIDER, F.; KUMAR, N.; NAQVI, A.A.; BAGCHI, G.D. Oil constituents of Artemisia nilagirica var. septentrionalis growing at different altitudes. Natural Product Communications, v.5, p. 19591960, 2010.

IARC. INTERNATIONAL AGENCY FOR RESEARCH ON CANCER. Aflatoxins: natural occurring aflatoxins (Group 1), aflatoxin $M$, (Group 2B). v.56. Lyon: IARC Scientific Publications, 1993.

KAMATOU, G.P.P.; VAN ZYL, R.L.; VAN VUUREN, S.F.; FIGUEIREDO, A.C.; BARROSO, J.G.; LIMA, R.K.L.; CARDOSO, M.G.; CAMPOS, M.; ANDRADE, M.A.A.; MELO, B.A.; RODRIGUES, V.G. Caracterização química e atividade inseticida do óleo essencial de Ageratum conyzoides L. sobre a lagarta-do-cartucho do milho Spodoptera frugiperda (SMITH, 1797) (Lepidoptera: Noctuidae). Biosciencies Journal, v.26, p.1-5, 2010.

MAGALHÃES, J.F.G.; VIANA, C.F.G.; ARAGÃO JUNIOR, A.G.M.; MORAES, V.; RIBEIRO, R.A.; VALE, M.R. Analgesic and antiinflammatory activities of Ageratum conyzoides in rats. Phytotherapy Research, v.11, p.183-188, 1998.
MARQUES-NETO, J.F.; LAPA, A., KUBOTA, M. Efeitos do Ageratum conyzoides Lineé no tratamento da artrose. Revista Brasileira Reumatologia, v.28, p.34-37, 1988.

MARTINS, A.P.; SALGUEIRO, L.R.; GONÇALVES, M.J.; VILA, R.; CANIGUERAL, S.; TOMI, F.; CASANOVA, J. Essential oil composition and antimicrobial activity of Ageratum conyzoides from S. Tomé and Príncipe. The Journal of Essential Oil Research, v.17, n.3, p.239-242, 2005.

MCLAFFERTY, F.W.; STAUFFER, D. NBS Registry of Mass Spectral. New York: John Wiley \& Sons, 1989.

MOURA, A.C.A.; SILVA, E.L.F.; FRAGA, M.C.A.; WANDERLEY, A.G.; AFIATPOUR, P.; MAIA, M.B.S. Anti-inflammatory and chronic toxicity study of the leaves of Ageratum conyzoides L. in rats. Phytomedicine, v.12, n. 1-2, p.138-142, 2005.

NOGUEIRA, J.H.C.; GONÇALEZ, E.; GALLETI, S.R.; FACANALI, R.; MARQUES, M.O.M.; FELÍCIO, J.D. Ageratum conyzoides essential oil as aflatoxin suppressor of Aspergillus flavus. International Journal of Food Microbiology, v. 137, p.55-60, 2010.

OKUNADE, A.L. Ageratum conyzoides L. (Asteraceae). Fitoterapia, v.73, n.1, p.1-16, 2002.

RAHIMMALEK, M.; TABATABAEI, B.E.S.; ETEMADIC, N.; GOLI, S.A.H.; ARZANI, A.; ZEINALI, H. Essential oil variation among and within six Achillea species transferred from different ecological regions in Iran to the field conditions. Industrial Crops and Products, v.29, n.2-3, p.348-355, 2009.

RANA, V.S.; BLAZQUEZ, M.A. Chemical composition of the volatile oil of Ageratum conyzoides aerial parts. The International Journal of Aromatherapy, v.13, n.4, p.203-206, 2003.

SHARMA, G.P.; JAIN, N.K.; GARG, B.D. Antifungal activity of some essential oils-I. Indian Drugs, v.16, p.21, 1978.

VIEIRA, G.D.V.; SOUSA, O.V.; YAMAMOTO, C.H.; KAPLAN, A.C. Chemical composition and antimicrobial activity of the essential oils of Ageratum fastigiatum (Asteraceae). Records of Natural Products, v.3, p.52-57, 2009.

XIE, Y.; HUANG, Q.; YANG, F.; LEI, C. Chemical variation in essential oil of Cryptomeria fortunei from various areas of China. Industrial Crops and Products, v.36, n. 1, p.308-312, 2012.

YIN, M.C.; TSAO, S.M. Inhibitory effect of seven Allium plants upon three Aspergillus species. International Journal of Food Microbiology, v.49, n.1-2, p.49-56, 1999. 